\title{
Hands on Training for Handling Electrical Equipments Manufacturing Machinaries
}

\author{
S.Jeni Theresa, N.Mathan Kumar, C.Archana Priya
}

\begin{abstract}
Getting ready and developing foresee a remarkable event in association reasonableness and in the workplace people's views. Preparation has guidelines for employee sustainability, stability and health and understanding. All allegiances that use people want their workers to prepare and grow. Many associations understand this important and put a considerable effort and money getting ready and progression Such theory may appear to be the use of commission scheduling and staff headway and the payment of compensation to staff that are gearing up and improved. The exuberance for gearing up and progressing involves the provision and maintenance of space and equipment. It also implies that the operating power, used in the critical business limits of the association, for example, formation, maintenance, arrangements The promotion and encouragement of the board will likewise promote their thinking and actions From time to time to support the growth and movement of preparation. This implies that they are expected to pay less respect to practices that are evidently gradually gainful to the extent of the important business of the affiliation. In any case, excitement for preparing and moving forward is usually regarded as an exceptional method of planning to keep up with the right bent now and later.
\end{abstract}

Keywords: assortment, recommendations

\section{INTRODUCTION}

In the field of Human resource the board, getting ready and progression is the field stressed over various leveled activity anticipated bettering the show of individuals and social affairs in legitimate settings. It has been known by a couple of names, including laborer improvement, human resource progression, and learning and improvement.

Planning and progression encompasses three key activities: getting ready, preparing, and improvement. Garavan, Costine, and Heraty, of the Irish Institute of Training and Development, note that these considerations are every now and again seen as synonymous. Regardless, to masters, they join three confined, but interrelated, practices setting up this activity is both focused upon, and surveyed against, the movement that a person starting at now holds. Preparing this activity focuses upon the vocations that an individual may conceivably hold later on, and is evaluated against those occupations. Improvement this development focuses upon the activities that the affiliation using the individual, or that the individual is a bit of, may share later on, and is for all intents and purposes hard to survey. [1]-[3]

Revised Manuscript Received on December 11, 2019

S.Jeni Theresa, Assistant Professor, Department Of Science \& Humanities, Bharath Institution Of Higher Education And Research,Tamilnadu,India.Email: littleflower1812@gmail.com

N.Mathan Kumar, Assistant Professor, Department Of Science \& Humanities, Bharath Institution Of Higher Education And Research Tamilnadu,India.Email: ma.aswinkumar18@gmail.com

C.Archana Priya Assistant Professor, Department Of Science \& Humanities, Bharath Institution Of Higher Education And Research Tamilnadu,India.Email: Archanapriya854@gmail.com

Getting ready is strategy of learning a gathering of modified lead. It is utilization of learning. It gives people recognition with the rules and strategies to deal with their direct. It attempts to improve their display on the present work environment or set them up for a proposed movement. Improvement is a related strategy. It covers these activities, which improve work execution, yet also these, which acknowledge improvement of the character; help individuals in the progression towards advancement and fulfillment of their potential points of confinement with the objective that they become extraordinary delegates just as better men and women. In various leveled terms, it is wanted to design individual for a more noteworthy and higher movement is progression. In addition, this may well fuse upsetting unequivocal capacities notice learning just as vaccinating certain character \&mental moods. In this sense, headway isn't altogether different from preparing.[4]-[8]

\section{NEED FOR BASIC PURPOSE OF TRAINING}

1. To increment profitability

2. To improve quality

3. To Help an organization meet its individual needs in the future to improve its authoritative environment

4. Obsolescence avoidance

5. Personnel development

\section{OBJECTIVES}

1. To know the opinion of the management and the Beneficiaries of Raj about the training and development of their organization.

2. To recommend solutions and suggestions also help to improve their training for the trainees.

\section{TRAINING METHODS}

Preparing is customarily depicted as tending to be categorized as one of two classifications at work preparing or off-the-work preparing. At work preparing happens when the student isn't expelled from the working environment. Preparing embraced along these lines has the upside of being promptly transferable to the work circumstance and is commonly viewed as modest and financially savvy. Be that as it may, it can likewise have all the earmarks of being irregular and indiscriminate in its apparatus our and application. [10]-[15] Off-the activity preparing happens when the learner is expelled from the working environment to (for example) go to an instructional class. While the substance of off-the-work preparing can be progressively sure, how much it tends to be applied back to the work spot isn't. 


\section{Hands on Training for Handling Electrical Equipments Manufacturing Machinaries}

\section{RESULTS}

$>$ The study reveals that $60 \%$ of the respondents have confidence with the superiors and $30 \%$ they having confidence with the superiors sometimes and $10 \%$ they don't have confidence with the superiors.

$>$ Regarding the training methods, $70 \%$ of the respondents were highly satisfied $20 \%$ were satisfied and $10 \%$ were not satisfied with the training methods.

$>$ The study also revealed that $64 \%$ of the respondents felt that they are satisfied with on the Job training and $36 \%$ were not satisfied with on the Job training.[16]-[20]

\section{SUGGESTIONS}

In the course of the study, the following are suggested to increase the Training and development of employees in Raj, Chennai.

$>$ Job training provided in the company is satisfactory, but it has to be increased further for better Job training.

$>$ Training facilities provided in the company was not at all satisfactory. Subsidized training must be provided with good quality.

$>$ Employees may be provided with better training to increase the development of the organization.

$>$ They suggestions were given for consideration of management, but it was left to the management to look into those aspects with a positive approach and take final decision.[21]-[25]

\section{CONCLUSION}

Training and development is the need one today and these two are interdependent with each other.

The study reveals that the employees are interest in the training but it should be grab the employees. I suggest that the Raj electronics management should concentrate in the development the way of training

This is enhancing the level of training to the employees. It is clear from the study that the employee in the Rajis fully satisfied with all the development provided to them. They are not satisfied with the training Technicalities and policies and training process.

For solving the problems the Board of Directors has to take necessary steps. They want to decide the program for full utilization of resources. Raj has realized and runs the programmes that improve the skills of the employees. It means operating of the basis meritocracy that you can get ahead in their work, regardless of one's background.

\section{REFERENCES}

1. Vasanthi, S. \& Rabiyathul Basariya, S. 2019, "Influence of value analysis and cross training in industry", International Journal of Engineering and Advanced Technology, vol. 8, no. 6, pp. 1810-1811.

2. Velvizhi, R., Sri Gowtham, S. \& Jeya Priya, D. 2019, "Examination of early feedbacks for effective product retailing on E-commerce websites", International Journal of Engineering and Advanced Technology, vol. 8, no. 6 Special Issue 2, pp. 703-706.

3. Anuradha, C., Pothumani, S. \& Kavitha, R. 2019, "A novel method towards E-commerce", International Journal of Engineering and Advanced Technology, vol. 8, no. 6 Special Issue 2, pp. 535-538.

4. Thomas, J. \& Rabiyathul Basariya, S. 2019, "A study on the issues of financial ratio analysis", Indian Journal of Public Health Research and Development, vol. 10, no. 3, pp. 1079-1081.

5. Ramachandran, S. \& Rabiyathul Basariya, S. 2019, "Online marketing study on customer satisfaction and relationship", Indian Journal of
Public Health Research and Development, vol. 10, no. 3, pp. 1072-1078.

6. Priya, R., Vinothini, G. \& Cor Jesu, C.D. 2019, "The mentor-protégé relationship for professional growth", Journal of Advanced Research in Dynamical and Control Systems, vol. 11, no. 9 Special Issue, pp. 1110-1119.

7. Jannifer Rani, N., Bina Pani, S. \& Nimisha, N.S. 2019, "A study on money back polices available in LIC", Journal of Advanced Research in Dynamical and Control Systems, vol. 11, no. 9 Special Issue, pp. 833-839

8. Saillaja, V., Jhansi Rani, K. \& Catherine, R. 2019, "Global marketing management planning and organization", Journal of Advanced Research in Dynamical and Control Systems, vol. 11, no. 9 Special Issue, pp. 489-493.

9. Saillaja, V., Jhansi Rani, K. \& Catherine, R. 2019, "The new phase of marketing information system", Journal of Advanced Research in Dynamical and Control Systems, vol. 11, no. 9 Special Issue, pp. 482-488.

10. Thoufiqulla \& Raju, D.V. 2019, "Perception of indian investor towards investment in mutual funds with special reference to mip funds", Journal of Advanced Research in Dynamical and Control Systems, vol. 11, no. 5, pp. 177-183.

11. Jasmine, K.R.M. \& Basariya, S.R. 2018, "A study on the customers benefits on mutual funds", International Journal of Civil Engineering and Technology, vol. 9, no. 4, pp. 45-48.

12. Vasanthi, S. \& Basariya, S.R. 2019, "Pros and cons of on the job training versus off the job training", International Journal of Scientific and Technology Research, vol. 8, no. 10, pp. 671-674.

13. Pavithra, J. \& Ganesan, M. 2016, "A study on awareness and impact of micro-financial schemes", International Journal of Applied Business and Economic Research, vol. 14, no. 8, pp. 5449-5460.

14. Pavithra, J., Dilli Babu, P. \& Ambuli, T.V. 2014, "A study on budgetary control at Maruti Service Masters, Chennai", International Journal of Applied Business and Economic Research, vol. 12, no. 2, pp. 151-161.

15. Gunaraja, T.M. \& Venkatrama Raju, D. 2018, "Determining factors of organisational climate with reference to leadership styles", International Journal of Mechanical Engineering and Technology, vol. 9, no. 9, pp. 1327-1332.

16. Gunaraja, T.M. \& Venkatrama Raju, D. 2018, "The role of job satisfaction and training of employees in determining organisational climate of a selected industry", International Journal of Civil Engineering and Technology, vol. 9, no. 8, pp. 1266-1269.

17. Aarathy, T.S. \& Raju, D.V. 2018, "Performance appraisal and its effects on employees with respect to it sector in Chennai city", International Journal of Civil Engineering and Technology, vol. 9, no. 6, pp. 1535-1538.

18. Aarathy, T.S. \& Raju, D.V. 2018, "Employee perception towards performance appraisal system in IT sector", International Journal of Mechanical Engineering and Technology, vol. 9, no. 5, pp. 131-135.

19. Porselvi, W., Jublee, D. \& Sivanesan, G. 2018, "A study on factors influencing adoption of technology and innovation in banking industry, tamilnadu, India", International Journal of Mechanical Engineering and Technology, vol. 9, no. 5, pp. 789-800.

20. Akessa, G.M. and Dhufera, A.G., 2015. Factors That Influences Students Academic Performance: A Case of Rift Valley University, Jimma, Ethiopia. Journal of Education and Practice, 6(22), pp.55-63.

21. Miller, G. and Shih, C.C., 1999. A faculty assessment of the academic rigor of on-and off-campus courses in agriculture. Journal of Agricultural Education, 40, pp.57-65

22. Tsinidou, M., Gerogiannis, V. and Fitsilis, P., 2010. Evaluation of the factors that determine quality in higher education: an empirical study. Quality Assurance in education, 18(3), pp.227-244.

23. Farooq, M.S., Chaudhry, A.H., Shafiq, M. and Berhanu, G., 2011. Factors affecting students' quality of academic performance: a case of secondary school level. Journal of quality and technology management, 7(2), pp.1-14.

24. Fitsilis, P., Gerogiannis, V. and Anthopoulos, L., 2014. Ontologies for software project management: a review. Journal of Software Engineering and Applications, 7(13), p.1096.

25. Adams, J.D. and Jaffe, A.B., 1996. Bounding the effects of R\&D: an investigation using matched establishment-firm data(No. w5544). National bureau of economic research. 


\section{AUTHORS PROFILE}

S.Jeni Theresa, Assistant Professor, Department Of Science \& Humanities, Bharath Institution Of Higher Education And Research,Tamilnadu,India

N.Mathan Kumar, Assistant Professor, Department Of Science \& Humanities, Bharath Institution Of Higher Education And Research Tamilnadu,India

C.Archana Priya Assistant Professor, Department Of Science \& Humanities, Bharath Institution Of Higher Education And Research Tamilnadu,India 